\title{
Variation of aerosol optical properties from AERONET observation at Mt. Muztagh Ata, Eastern Pamirs
}

\author{
Ni Yan ${ }^{\mathrm{a}, \mathrm{b}}$, Guangjian $\mathrm{Wu}^{\mathrm{a}}$, Xuelei Zhang ${ }^{\mathrm{c}}$, Chenglong Zhang ${ }^{\mathrm{d}}$, Tianli Xu ${ }^{\mathrm{a}, \mathrm{b}}$, Lazhu ${ }^{\mathrm{a}, \mathrm{b}}$ \\ ${ }^{a}$ Key Laboratory of Tibetan Environment Changes and Land Surface Processes, Institute of Tibetan Plateau Research, Chinese Academy of Sciences, Beijing 100101, China \\ b University of Chinese Academy of Sciences, Beijing 100049, China \\ ${ }^{c}$ Northeast Institute of Geography and Agroecology, Chinese Academy of Sciences, Changchun 130102, China \\ ${ }^{\mathrm{d}}$ Research Center for Eco-Environmental Sciences, Chinese Academy of Sciences, Beijing, 100085, China
}

\section{A R T I C L E I N F O}

\section{Article history:}

Received 12 June 2014

Received in revised form 15 October 2014

Accepted 17 October 2014

Available online 23 October 2014

\section{Keywords:}

AERONET

Muztagh Ata

Aerosol optical depth

Ångström exponent

Volume size distribution

\begin{abstract}
A B S T R A C T
Using data from the ground-based remote sensing Aerosol Robotic Network (AERONET), aerosol optical properties, including aerosol optical depth (AOD), Ångström exponent $(\alpha)$, and volume size distribution were investigated for the period June to December 2011 at Mt. Muztagh Ata (Muztagata), Eastern Pamirs. The monthly average values of AOD (500 nm) and $\alpha(440-870 \mathrm{~nm})$ varied from $0.08 \pm 0.02$ to $0.16 \pm 0.11$, and from $0.56 \pm 0.06$ to $0.93 \pm 0.28$, respectively. The daily AOD averages $0.14 \pm 0.07$, with the maximum (0.5) occurring in August and the minimum (0.05) occurring in November. A small increase in AOD is expected with a noticeable decrease in the $\alpha$ value. The daily $\alpha$ averages $0.70 \pm 0.27$, and most exponents are less than 1 , indicating the majority of larger aerosol particles. The volume size distribution of aerosol particles shows bimodal log-normal characteristics, with a fine mode radius of $0.2 \mu \mathrm{m}$ and a coarse mode radius of $3 \mu \mathrm{m}$. The MODIS AOD and AERONET AOD display a similar variation, while the former is always noticeably higher than the latter with a difference of $0.1-0.4$, indicating that the MODIS data might overestimate the aerosol load. Our results indicate that high aerosol volume concentration occurs in summer with the dominance of coarse particles over Muztagh Ata. The low AOD shows a clean atmosphere in this region, revealing that it is an atmospheric background site for continental aerosol monitoring.
\end{abstract}

(C) 2014 Elsevier B.V. All rights reserved.

\section{Introduction}

Aerosols are important atmospheric components, and the way they influence regional and global climate change is not well understood. They alter the radiative balance of the atmosphere directly by absorbing and scattering solar radiation, and indirectly by changing the microphysical process of cloud (acting as ice nuclei) and precipitation efficiency (acting as cloud condensation nuclei) (Ramanathan et al., 2001). Aerosol optical properties are the key parameters to determine radiative forcing (Holben et al., 1998). Due to the strong regional to local distribution of aerosol, these properties are not well understood, particularly in remote regions.

E-mail address: wugj@itpcas.ac.cn (G.Wu).
The Tibetan Plateau, with its unique geographical features, plays an important role in atmospheric circulation and climate change in Asia. It is surrounded by huge natural aerosol source regions, with West Asia deserts to the west, the Thar Desert to the southwest, and the Taklimakan Desert and other arid and semi-arid regions to north. Aerosols, such as mineral aerosols (here referred to as dust) and carbonaceous aerosol, from these sources can be lifted up to the mid-upper troposphere and transported to the Tibetan Plateau. Over the past few decades, numerous studies have investigated the geochemical composition of aerosols on the Tibetan Plateau and have shown that aerosols there are predominantly from natural sources (e.g. dust), such as found along the Himalayas (Wake et al, 1994), Mt. Muztagh Ata (Cao et al., 2009; Wu et al., 2009), Mt. Waliguan (Wen et al., 2001), Nam Co (Cong et al., 2007), and the southeastern Tibetan Plateau (Zhang et al., 2012). However, 
short-term aerosol sampling at a given site is insufficient to fully understand long-term temporal and large-scale spatial variation of aerosol properties over this remote region. Furthermore, long-term ground-based observation data is difficult to collect in this remote high altitude region due to the adverse climatic and geographical conditions, and the challenging logistics.

Ground-based remote sensing can provide long-term observation of multiple spectral characteristics of aerosol properties using retrieval methods. However, the retrieval of satellitebased remote sensing has complex algorithms and is difficult to interpret over reflective surfaces, such as deserts and glaciers (Remer et al., 2005). The retrieval of aerosol optical properties at high altitudes and for light-colored surface regions continues to be one of the main challenges in remote sensing. Only a few sites have carried out aerosol optical property observations using the Aerosol Robotic Network (AERONET) on and around the Tibetan Plateau, such as Nam Co in central Tibet $\left(30.77^{\circ} \mathrm{N}\right.$, $90.96^{\circ} \mathrm{E}, 4730 \mathrm{~m}$ a.s.l., Cong et al., 2009; Xia et al., 2011), IssykKul Lake in the northern Pamirs $\left(42.62^{\circ} \mathrm{N}, 76.98^{\circ} \mathrm{E}, 1650 \mathrm{~m}\right.$ a.s.l., Semenov et al., 2005), and at the center of Taklimakan Desert (Che et al., 2013). Other studies have reported on aerosol optical properties over high altitude regions, such as Lhasa and Haibei on the Tibetan Plateau (Xin et al., 2007), and Hanle Station in the trans-Himalayan region (Ningombam et al., 2014). In this study, we investigate the basic characteristics of aerosol optical properties using AERONET observations, including aerosol optical depth (AOD), Ångström exponent $(\alpha)$, volume size distribution, and their variations in summer and autumn at Mt. Muztagh Ata, Eastern Pamirs, in order to provide a better understanding of aerosol properties and to reduce the uncertainty of aerosol radiative forcing estimated from satellite observations.

\section{Observation and data}

\subsection{Observation}

The Muztagh Ata (Muztagata, $38.41^{\circ} \mathrm{N}, 75.04^{\circ} \mathrm{E}, 3674 \mathrm{~m}$ ) AERONET site is located in the courtyard of Muztagh Ata Station for Westerly Environment Observation and Research (MASWE), Eastern Pamirs (Fig. 1). This site is surrounded by high mountains, and the prevailing high level winds are the perennial Westerlies. Meteorological parameters including temperature, precipitation and wind speed from MASWE for the period June to December 2011 are given in Fig. 2 (a total of 183 days). Over this period, monthly average temperature ranged from $-1.29{ }^{\circ} \mathrm{C}$ in December to $12{ }^{\circ} \mathrm{C}$ in August. Precipitation was relatively low, with most occurring in September. Summer wind speeds are lower than in autumn. The maximum wind speed of $8.6 \mathrm{~m} / \mathrm{s}$ was recorded in November.

A Cimel 318 sun photometer was set up at this site, which can record the direct solar radiation and diffuse sky radiation with a $1.2^{\circ}$ full field of view. The direct solar radiation observations were performed in eight spectral bands (340 nm, $380 \mathrm{~nm}, 440 \mathrm{~nm}, 500 \mathrm{~nm}, 675 \mathrm{~nm}, 870 \mathrm{~nm}$, $940 \mathrm{~nm}$, and $1020 \mathrm{~nm}$ ) (http://aeronet.gsfc.nasa.gov/new web/equipment_details.html). All filters for standard sunphotometer are narrow-bands with the bandwidth of $10 \mathrm{~nm}$, except $2 \mathrm{~nm}$ for 380 and $340 \mathrm{~nm}$, respectively. The sky radiance observations were performed in four spectral bands (440 nm, $670 \mathrm{~nm}, 870 \mathrm{~nm}$, and $1020 \mathrm{~nm}$ ). We can acquire polarization measurement of the sky at $870 \mathrm{~nm}$, derive column water vapor content at $940 \mathrm{~nm}$, and retrieve aerosol optical properties at other spectral bands.

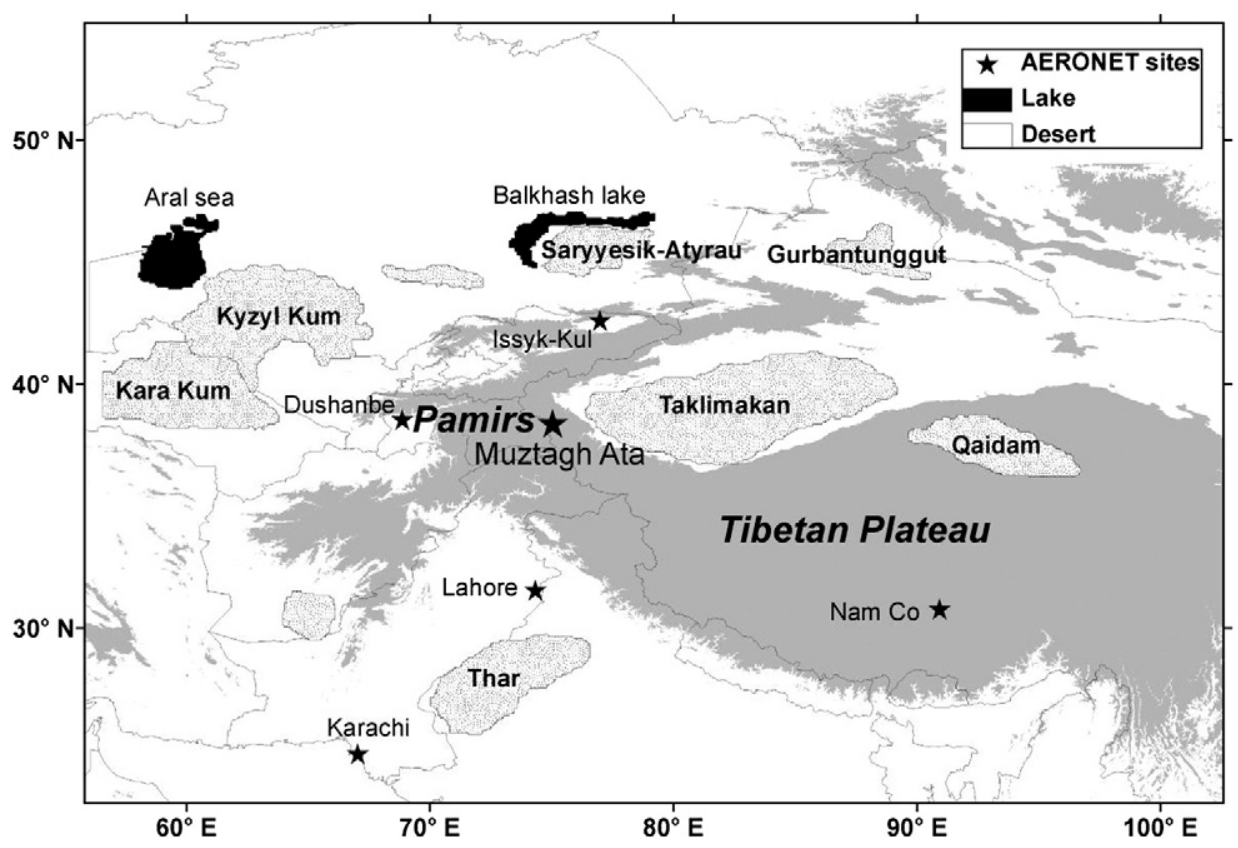

Fig. 1. The location of Muztagh Ata and other AERONET sites over and near the Tibetan Plateau. 


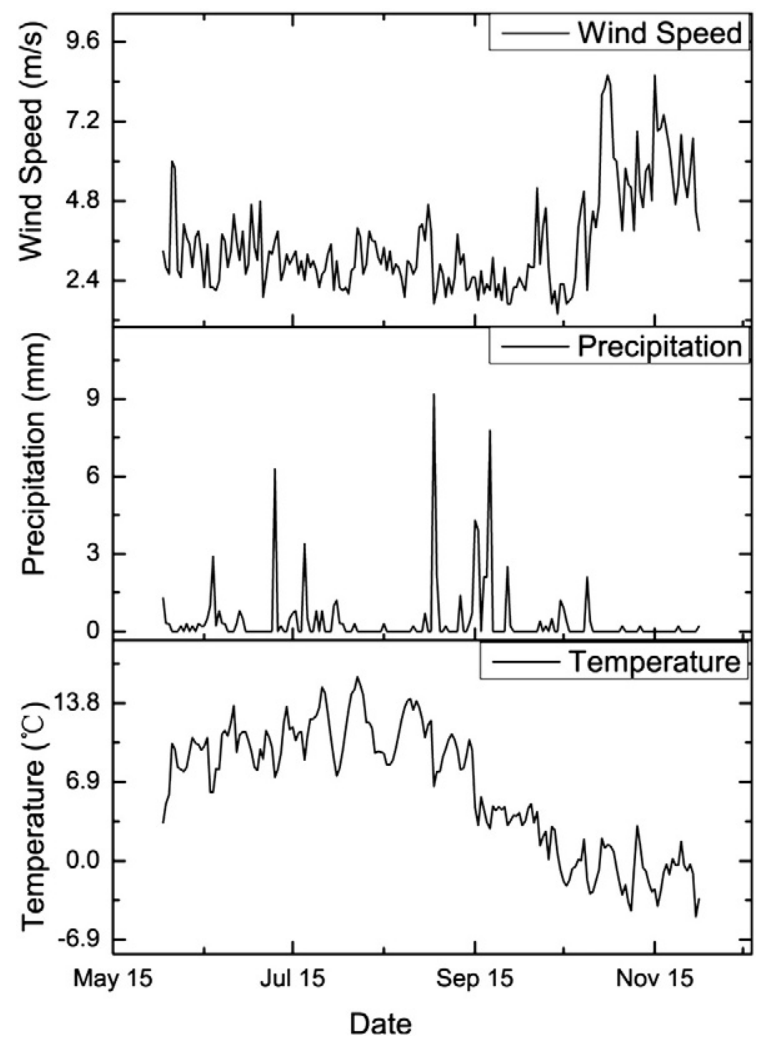

Fig. 2. The meteorological parameters for the study area for the period June to December, 2011.

\subsection{AERONET and MODIS data}

The calibration of this instrument and accuracy assessment of AERONET aerosol optical properties have been discussed previously in detail (e.g. Dubovik et al, 2000; Holben et al., 1998; Smirnov et al., 2000). Here we simply describe the retrieval accuracy for aerosol optical properties. Under cloud-free conditions, the uncertainty in the retrieval of AOD is at the level of \pm 0.01 for wavelength $\geq 440 \mathrm{~nm}$ and \pm 0.02 for wavelength $<440 \mathrm{~nm}$ (Eck et al., 1999). In this paper, we use AOD values at wavelength $500 \mathrm{~nm}$. The error of the retrieval of volume particle size distribution does not exceed $15 \%-35 \%$ for each particle size bin for $0.1 \leq r \leq 7 \mu \mathrm{m}$, depending on aerosol type. However, this error can increase to $35 \%-100 \%$ for ultrafine particles $(0.05 \leq r \leq 0.1 \mu \mathrm{m})$ and coarse particles $(7 \leq r \leq 15 \mu \mathrm{m})$ (Dubovik et al., 2000).

There are three levels of AERONET (http://aeronet.gsfc.nasa. gov/) data. The Level 1.5 data is cloud screened (Smirnov et al., 2000), while Level 2.0 data is cloud screened and quality assured (Holben et al., 1998). In this paper, we use Level 2.0 data to analyze variation of the AOD, the $\alpha$ and the first derivative of the $\alpha$, while using Level 1.5 data to show the variation of volume size distribution over Mt. Muztagh Ata, because there is very few effective Level 2.0 data for size distribution during the observation period. We grouped the AERONET data into summer (June to August) and autumn (September to November) seasons. Furthermore, there is little data for December over the whole of the observation period (5 days in December 2011).
The MODIS (Moderate Resolution Imaging Spectroradiometer) data on the Terra satellite at Level 3 atmospheric products (Data product info: MODIS-Terra version 5.1) with spatial resolution of $1^{\circ} \times 1^{\circ}$ are also used in this paper (http:// disc.sci.gsfc.nasa.gov/giovanni/overview/index.html). Remer et al. (2005) predicted the uncertainty of $\Delta \tau= \pm 0.05 \pm 0.15 \tau$ for MODIS AOD over land. Other research also assessed the MODIS aerosol optical depth retrieval error of $\Delta \tau= \pm 0.05 \pm$ $0.2 \tau$ (Chu et al., 2002). We compared the MODIS AOD with the AERONET AOD at the same wavelength of $550 \mathrm{~nm}$ for the same period in order to discuss the validity and calibration of MODIS products at this site.

\section{Results and discussion}

\subsection{Variation of $A O D$ and $\alpha$}

The variations of the daily and monthly averaged AOD (500 nm) and $\alpha(440-870 \mathrm{~nm})$ values at the Muztagh Ata site for the period June to December 2011 (114 days with effective data) are shown in Fig. 3. The AOD value is higher in summer than that in autumn, with the maximum monthly average AOD of $0.16 \pm 0.11$ in August and the minimum monthly average AOD of $0.08 \pm 0.02$ in November. The seasonal variation trend of AOD over this area is consistent with the microparticle concentration record in the nearby ice cores (15 km south, at $6350 \mathrm{~m}$ a.s.l.) and the dust aerosol concentration from an aerosol sampling site (14 km south, at $4430 \mathrm{~m}$ a.s.l.) over Eastern Pamirs (Wu et al., 2008, 2009), because of high dust load caused by frequent dust storm events in summer over the West and Central Asian deserts. Furthermore, there was some precipitation in September 2011, which might contribute to the lower AOD in this month. The near-surface wind speed is higher in summer than in autumn, and reached its maximum in November. However, the correlation between the wind speed and the AOD is not clear during the observation period.

The average daily AOD value throughout the entire observation period is $0.14 \pm 0.07$, and most daily values range from $0.05 \pm 0.01$ to $0.25 \pm 0.02$. The mean of daily AOD values at this site is close to that of the nearby Issyk-Kul Lake site $(A O D=0.1$ at altitude $1650 \mathrm{~m}$ a.s.l.) in Central Asia (Semenov et al., 2005), and that of the Hanle Station in the trans-Himalaya $(A O D=0.04$ at altitude $4500 \mathrm{~m}$ a.s.l., using the Prede skyradiometer) (Ningombam et al., 2014), while slightly higher than that at Nam Co (AOD $=0.05$ at altitude $4730 \mathrm{~m}$ a.s.l.) in the central Tibetan Plateau (Cong et al., 2009) (Table 1). This is possibly because Nam Co is far away from the Asian dust source regions and is located at a relatively higher altitude.

Compared to the Dushanbe site (averaging 0.36) at the same latitude $\left(38.55^{\circ} \mathrm{N}, 68.84^{\circ} \mathrm{E}, 821 \mathrm{~m}\right.$ a.s.l.), the average daily AOD value at Muztagh Ata is noticeably low, using the AERONET Level 2.0 data set for the same period July to December 2011. Dushanbe is located at a somewhat lower altitude and is closer to dust source regions (e.g. Afghanistan, Iran Plateau, Kara Kum, Kyzyl Kum). Both Muztagh Ata and Dushanbe have several extremely high AOD values in August 2011, a time of year associated with dust storm outbreaks in the upwind arid regions, such as Afghanistan, where dust storm events occur most frequently in August (Middleton, 1986). The monthly average of AOD values at Muztagh Ata (from 0.08 to 

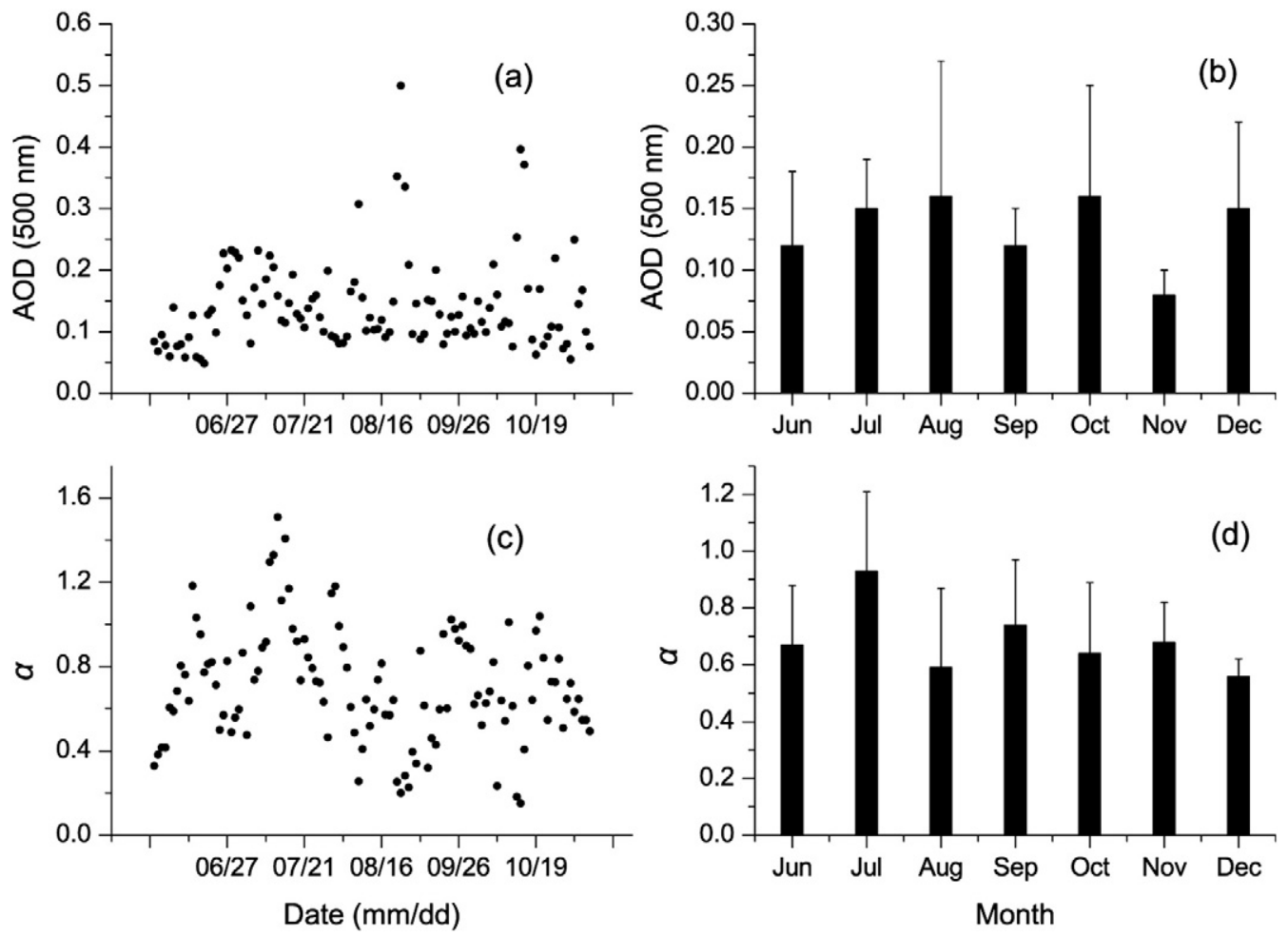

Fig. 3. The daily (a) and monthly (b) AERONET AOD at $500 \mathrm{~nm}$, and the daily (c) and monthly (d) averaged $\alpha$ at $440-870$ nm for the period June to December 2011 over Muztagh Ata.

$0.16)$ is much lower than that at Lahore $\left(31.54^{\circ} \mathrm{N}, 74.32^{\circ} \mathrm{E}\right.$, $270 \mathrm{~m}$ a.s.l., from 0.57 to 0.76$)$ and Karachi $\left(24.87^{\circ} \mathrm{N}, 67.03^{\circ} \mathrm{E}\right.$, $49 \mathrm{~m}$ a.s.l., from 0.33 to 0.63 ), both located near deserts (e.g. Thar Desert) and at lower altitudes (Alam et al., 2011, 2012). Therefore, the Muztagh Ata shows a clean atmospheric environment and can serve as a background site for continental aerosol monitoring.

The $\alpha$ value, which is determined from the spectral dependence of the measured optical depth, can provide useful characteristics of aerosol particle size (Eck et al., 1999). A high $\alpha$ value $(>1)$ indicates a major contribution of fine particles, while a low $\alpha$ value $(<1)$ simply indicates the dominance of coarse particles (e.g. Kaufman, 1993). The desert dust shows a low $\alpha$ with values in the range -1 to 0.5 (Tanré et al., 2001) and
-0.1 to 1.2 (Dubovik et al., 2002), while the urban-industrial and mixed aerosols (1.2-2.5) and biomass burning particles (1.0-2.3) (Dubovik et al., 2002), particularly smokes (>2.4), show a high $\alpha$ value (Kaufman et al., 1992). From the AERONET data, the daily $\alpha$ averages $0.70 \pm 0.27$ (varying from $0.15 \pm$ 0.05 to $1.51 \pm 0.09)$ at Muztagh Ata. The maximum monthly mean $\alpha$ value $(0.93 \pm 0.28)$ occurs in July, and the minimum $(0.56 \pm 0.06)$ occurs in December (Fig. 3c). The number of days with $\alpha<1$ accounts for $87 \%$ of the total over the whole observation period, indicating the presence of mainly coarse aerosol particles at this site.

The mean of all of the daily Muztagh Ata $\alpha$ values for the measurement period is close to that of Hanle Station $(\alpha=0.85)$ (Ningombam et al., 2014) and Nam Co site ( $\alpha=0.57$ ) (Cong

Table 1

Statistics of monthly averaged AOD and $\alpha$ at Muztagh Ata and comparison with other sites.

\begin{tabular}{|c|c|c|c|c|c|c|c|c|}
\hline & \multicolumn{2}{|l|}{ Muztagh Ata } & \multicolumn{2}{|l|}{ Dushanbe $^{a}$} & \multicolumn{2}{|l|}{ Issky-Kul $^{\text {b }}$} & \multicolumn{2}{|l|}{$\mathrm{Nam} \mathrm{Co}{ }^{\mathrm{c}}$} \\
\hline & $\mathrm{AOD} \pm \mathrm{SD}$ & $\alpha \pm \mathrm{SD}$ & $\mathrm{AOD} \pm \mathrm{SD}$ & $\alpha \pm \mathrm{SD}$ & $\mathrm{AOD} \pm \mathrm{SD}$ & $\alpha \pm \mathrm{SD}$ & $\mathrm{AOD} \pm \mathrm{SD}$ & $\alpha \pm \mathrm{SD}$ \\
\hline Jun & $0.12 \pm 0.06$ & $0.67 \pm 0.21$ & - & - & $0.12 \pm 0.06$ & $1.31 \pm 0.33$ & $0.06 \pm 0.03$ & $0.25 \pm 0.28$ \\
\hline Jul & $0.15 \pm 0.04$ & $0.93 \pm 0.28$ & $0.33 \pm 0.06$ & $0.48 \pm 0.14$ & $0.14 \pm 0.07$ & $1.46 \pm 0.39$ & $0.05 \pm 0.02$ & $0.26 \pm 0.29$ \\
\hline Aug & $0.16 \pm 0.11$ & $0.59 \pm 0.28$ & $0.48 \pm 0.41$ & $0.45 \pm 0.19$ & $0.13 \pm 0.05$ & $1.45 \pm 0.30$ & $0.06 \pm 0.02$ & $0.90 \pm 0.32$ \\
\hline Sep & $0.12 \pm 0.03$ & $0.74 \pm 0.23$ & $0.28 \pm 0.11$ & $0.57 \pm 0.18$ & $0.12 \pm 0.06$ & $1.24 \pm 0.33$ & $0.05 \pm 0.02$ & $0.71 \pm 0.26$ \\
\hline Oct & $0.16 \pm 0.09$ & $0.64 \pm 0.25$ & $0.47 \pm 0.57$ & $0.73 \pm 0.42$ & $0.09 \pm 0.06$ & $1.12 \pm 0.36$ & $0.03 \pm 0.01$ & $0.68 \pm 0.32$ \\
\hline Nov & $0.08 \pm 0.02$ & $0.68 \pm 0.14$ & $0.15 \pm 0.06$ & $1.42 \pm 0.09$ & $0.07 \pm 0.05$ & $1.33 \pm 0.32$ & $0.03 \pm 0.01$ & $0.61 \pm 0.25$ \\
\hline Dec & $0.15 \pm 0.07$ & $0.56 \pm 0.06$ & $0.28 \pm 0.16$ & $1.49 \pm 0.20$ & $0.06 \pm 0.04$ & $1.41 \pm 0.31$ & - & - \\
\hline Mean & $0.14 \pm 0.07$ & $0.70 \pm 0.27$ & $0.36 \pm 0.35$ & $0.74 \pm 0.44$ & $0.10 \pm 0.03$ & $1.33 \pm 0.12$ & $0.05 \pm 0.01$ & $0.57 \pm 0.26$ \\
\hline
\end{tabular}

\footnotetext{
a http://aeronet.gsfc.nasa.gov.

b Semenov et al., 2005.

c Cong et al., 2009.
} 
et al., 2009), but clearly lower than that at Issyk-Kul lake (1.33) (Semenov et al., 2005) (Table 1), indicating the presence of relatively coarse aerosol particles in this region (or comparatively high levels of dust), although Muztagh Ata is located at a higher altitude than Issyk-Kul. This is likely due to more pollution from human activities in Issyk-Kul compared to Muztagh Ata. The daily averaged Muztagh Ata $\alpha$ shows a similar range (from -0.02 to 1.92 ) to that of Dushanbe for the same observation period. The monthly averaged $\alpha$ at Dushanbe shows low values from July to October and high values from November to December, implying that coarse particles are dominant in the warmer months, while fine particles increase in colder months, possibly due to the presence of cogeneration power stations (using oil and coal as fuel) and the use of coal for domestic winter heating there (Dr. S.F. Abdullaev, personal communication).

The total suspended particle dust aerosol collected at Muztagh Ata is about $6.36 \mu \mathrm{g} \mathrm{m}^{-3}$, assuming that the element $\mathrm{Al}$ (from 31 to $3395 \mathrm{ng} \mathrm{m}^{-3}$ ) contributes a value of $8 \%$ of the average upper continental crust (Wu et al., 2009). The annual average of element carbon (EC) and organic carbon (OC) concentration in this region (at the same dust aerosol sampling site) is $0.055 \mu \mathrm{g} \mathrm{m}^{-3}$ and $0.48 \mu \mathrm{g} \mathrm{m}^{-3}$, respectively (Cao et al., 2009). Therefore, the in-situ geochemical analysis indicates that mineral dust is the main component of aerosols over this region.

\subsection{Relationship between AERONET AOD and $\alpha$ index}

The scatter diagram of AOD and $\alpha$ for the period June to December 2011 over Muztagh Ata is given in Fig. 4, showing a trend of increases in AOD with decreases in $\alpha$. Although this trend is not obvious, it is worth noting that there is a wide range of $\alpha$ when the AOD value is less than 0.25 , suggesting that the correlation between the grain size of aerosol particles and aerosol concentration is not straightforward under the low AOD conditions at this site. Generally, this relationship is comparable to that at the Lhasa $\left(29.67^{\circ} \mathrm{N}, 91.33^{\circ} \mathrm{E}\right)$ and Haibei $\left(37.45^{\circ} \mathrm{N}, 101.32^{\circ} \mathrm{E}\right)$ sites in the Chinese Sun Hazemeter Network (CSHNET) on the Tibetan Plateau, where the low

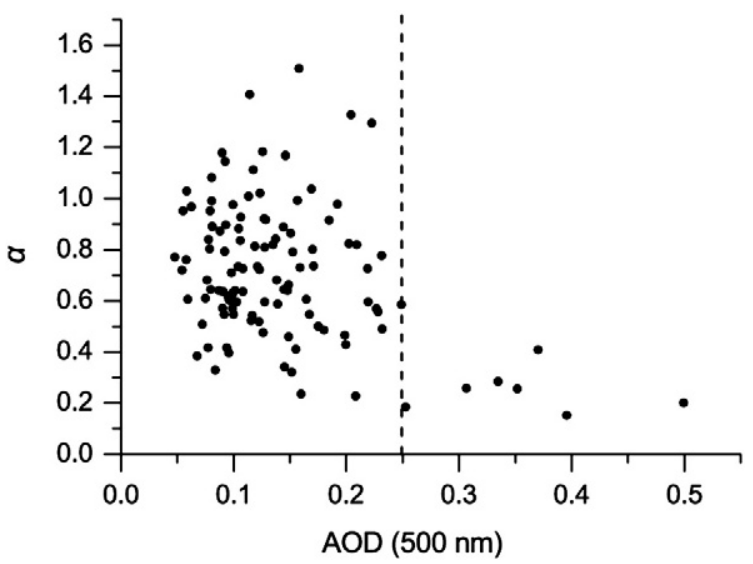

Fig. 4. The scatter plot of AOD at $500 \mathrm{~nm}$ and $\alpha$ at $440-870 \mathrm{~nm}$. annual mean of AOD value (about 0.15) corresponds to a wide range of $\alpha$ value (from 0.06 to 0.9 ) (Xin et al., 2007). Moreover, there are some instances of high $\alpha(>1.0)$ in July at Muztagh Ata, indicating that there is likely to be a presence of other types of aerosol, such as EC and OC from biomass burning, for which the maximum concentration is in summer (Cao et al., 2009). High AOD values are accompanied by low $\alpha$ values, indicating that coarse particles dominate under high aerosol concentration over this region. Tanré et al. (2001) have pointed out that desert dust over Sahara has a low $\alpha$ value but high AOD, which is in accordance with our Muztagh Ata result. The trend of increasing AOD with decreasing $\alpha$ becomes apparent over the Taklimakan Desert (Che et al., 2013), possibly due to the more frequent dust events at the Taklimakan site compared to Muztagh Ata.

\subsection{Comparison of AOD values between AERONET and MODIS}

AOD data can be obtained from satellite-based and groundbased remote sensing, both of which can provide long term observations of aerosol optical properties. It has been reported that there is a significant overestimation of MODIS AOD values over the land around the world, and most MODIS retrievals are noticeably higher than that of AERONET, especially in the case of low AOD level (e.g. Xia, 2006). A previous study also found that compared to the AERONET the MODIS AOD value is overestimated at Nam Co site on the Tibetan Plateau (Cong et al., 2009). Therefore, ground-based remote sensing is needed to obtain aerosol optical properties and to validate satellite remote sensing results over the Eastern Pamirs.

The scatter plot of the MODIS AOD and the AERONET AOD over Mt. Muztagh Ata is shown in Fig. 5. In order to provide an effective comparison between MODIS AOD and AERONET AOD at the same wavelength, the daily average values of AOD from AERONET are interpolated to wavelength of $550 \mathrm{~nm}$ of MODIS using the following computation (Alam et al., 2014):

$\mathrm{AOD}_{550 \mathrm{~nm}}=\mathrm{AOD}_{500 \mathrm{~nm}}\left(\frac{550}{500}\right)^{-\alpha}$,

where $\alpha$ is the Ångström exponent from the wavelength of $440-870 \mathrm{~nm}$. The error in the interpolation varies from $0 \%$ to $10 \%$ for different aerosol types (Remer et al., 2005). Nevertheless, giving a reasonable comparison for the two types of AOD, we intentionally chose days where both MODIS and AERONET data were available during the observation period. It is clear that the daily MODIS AOD always has a larger value than the AERONET AOD, with a difference of 0.1-0.4. Furthermore, the difference seems to be greater in summer than in autumn. This indicates that the MODIS AOD data overestimates the actual aerosol load over this region. Nevertheless, both the MODIS and AERONET AOD values show a very similar trend and have a strong correlation $(R=0.74)$ with root mean square error (RMSE) of 0.08. Xia (2006) found the good relationship between MODIS AOD and AERONET AOD, with the correlation coefficient of 0.66 (at $440 \mathrm{~nm}$ ) for Aqua and 0.69 (at $440 \mathrm{~nm}$ ) for Terra, respectively. Grosso and Paronis (2012) also showed a good agreement $(R=0.78)$ between MODIS and AERONET AOD data. Therefore, we can use this correlation to validate and calibrate the MODIS data. 

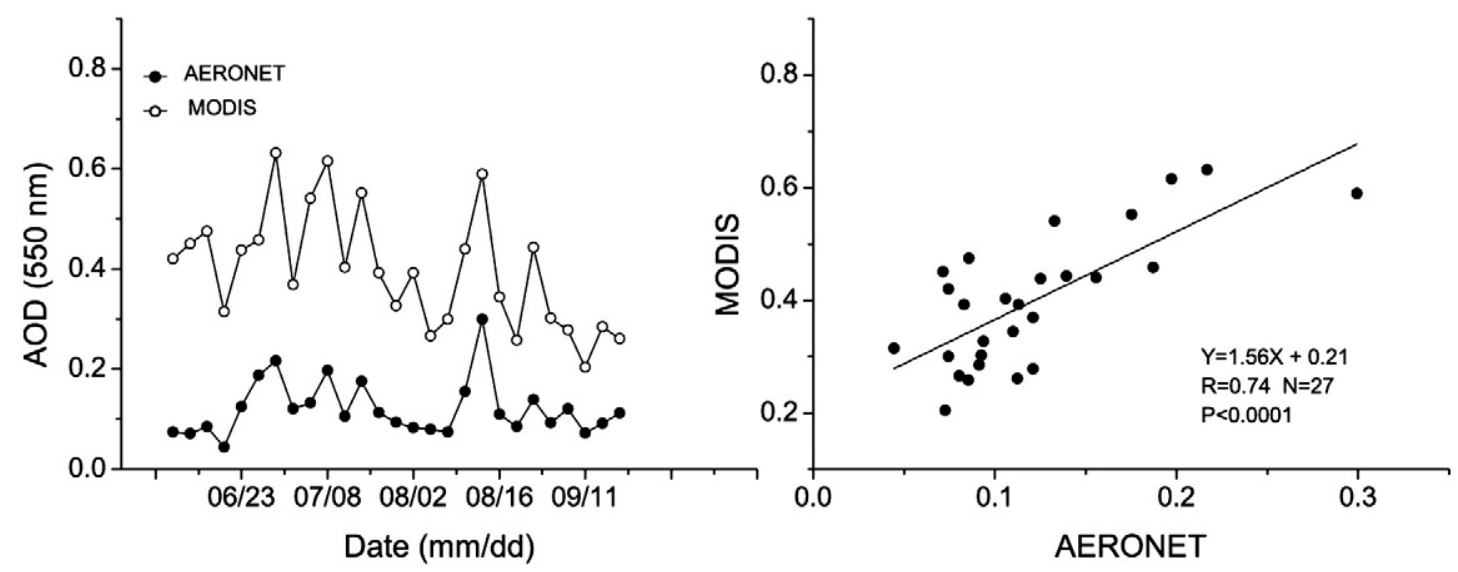

Fig. 5. Comparison of the MODIS AOD (550 nm) with the AERONET AOD $(500 \mathrm{~nm})$ for the period June to September 2011 over Muztagh Ata.

\subsection{Aerosol volume size distribution}

The volume size distribution of aerosol derived from the AERONET observation can be expressed by a log-normal distribution mode (Dubovik et al., 2002):

$\frac{\mathrm{d} V}{\mathrm{~d} \ln r}=\sum_{i=1}^{2} \frac{C_{v, i}}{\sigma_{i} \sqrt{2 \pi}} \exp \left[-\frac{\left(\ln r-\ln r_{v, i}\right)^{2}}{2 \sigma_{i}^{2}}\right]$,

where $\mathrm{d} V / \mathrm{d} \ln r$ denotes the aerosol volume size distribution, $i$ is the aerosol mode $\left(i_{1}\right.$ and $i_{2}$ represent the fine and coarse mode of aerosol, respectively), $C_{v, i}$ is the particle volume concentration, $r$ is the particle radius, $r_{v, i}$ is the volume median radius and $\sigma_{i}$ is the standard deviation.

The particle volume size distribution $(0.05 \mu \mathrm{m} \leq r \leq 15 \mu \mathrm{m})$ during summer and autumn over Muztagh Ata shows clear bimodal log-normal characteristics (Fig. 6a), indicating that the fine and coarse particles exist simultaneously. In this study, we define particles with radius less than $0.6 \mu \mathrm{m}$ as the fine fraction and particles with radius larger than $0.6 \mu \mathrm{m}$ as the coarse fraction, corresponding to separation point around $0.6 \mu \mathrm{m}$ between the fine and coarse mode (Dubovik et al., 2002). The volume size distribution of aerosol shows that the coarse mode radius is $3 \mu \mathrm{m}$, while the fine mode radius is about $0.2 \mu \mathrm{m}$. In summer, the coarse mode contributes the majority (85\% to the total) of aerosol volume and is about five times higher than that of the fine mode. In autumn, the coarse mode contributes $77 \%$ to the total aerosol volume and is about three times higher than that of the fine mode. In both summer and autumn, the fine mode contributes the same fraction to the total aerosol volume, while the coarse mode aerosol volume in summer is higher than in autumn with a ratio of 1.7. Wu et al. (2009) found that dust particle from the nearby Muztagh Ata ice cores obeys the log-normal law in volume-size distribution, with a mode diameter of 3.0 to $10.5 \mu \mathrm{m}$. Other researches on aerosol volume size distribution also have been discussed at the surrounding sites using AERONET data set. Cong et al. (2009) showed that the fine and coarse mode radius of aerosol particles is 0.2$0.3 \mu \mathrm{m}$ and $\sim 5 \mu \mathrm{m}$ respectively from AERONET data at Nam Co region on the central Tibetan Plateau. At Karachi, aerosol particle has the mode diameter of about $0.15 \mu \mathrm{m}$ and $3 \mu \mathrm{m}$ for the fine and coarse mode, respectively (Alam et al., 2011), and the coarse mode increases significantly for the dusty days compared to the non-dusty days (Alam et al., 2014).

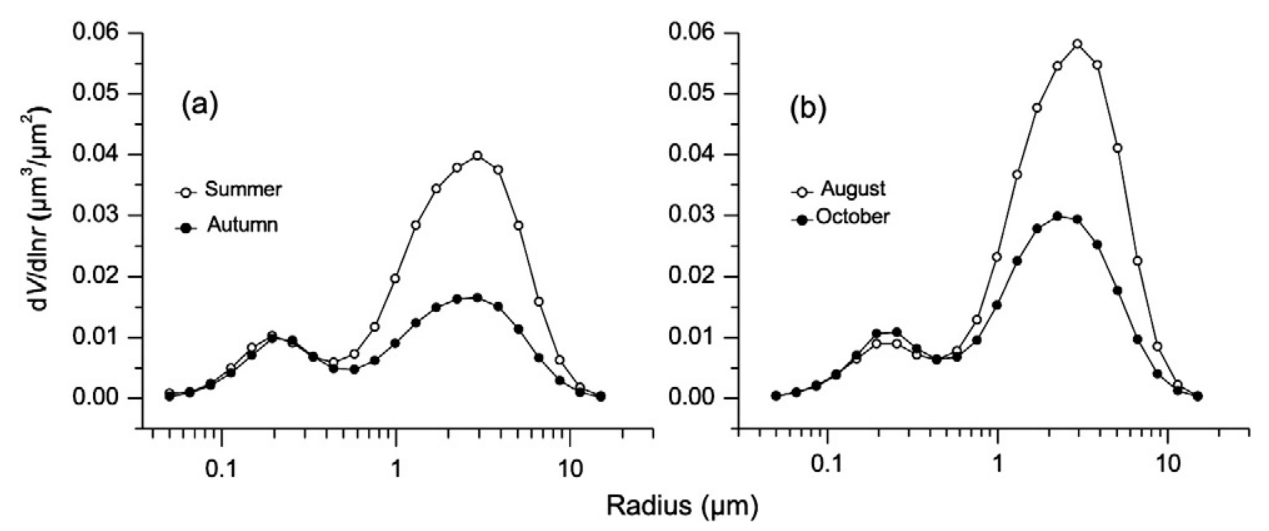

Fig. 6. Aerosol volume size distributions over Muztagh Ata. 
The first derivative of $\alpha$ ( $\alpha^{\prime}$ hereafter) is often used to describe the relative influence of fine mode over coarse mode particles. Eck et al. (1999) suggested that a significant decrease of $\alpha^{\prime}$ value is due to the addition of coarse particles to the volume size distribution. Fig. 7 gives the daily plot between Muztagh Ata AOD and $\alpha^{\prime}$ for each month. Except for October, most daily $\alpha^{\prime}$ values are negative, implying that the coarse particles dominate. All the $\alpha^{\prime}$ values are negative in August, indicating that the larger particles are the predominant component of aerosols and are influenced by frequent dust events. In October, the majority of $\alpha^{\prime}$ values are positive, suggesting that the contribution of fine particles to the volume size distribution has increased. From the size distribution, it can be seen that the coarse particles still form the major contribution to total volume both in August and October (Fig. 6b). In October the coarse particle fraction decreases while the fine particle fraction increases slightly compared to August. This difference might be responsible for the positive $\alpha^{\prime}$ in October.

\section{Possible aerosol sources and origins}

The AOD and aerosol particle size show a variation over Mt. Muztagh Ata for the period observed, suggesting a variety of aerosol types and complex aerosol sources. In this study, the NOAA HYPSLIT back-trajectory model (http://ready.arl.noaa. gov/HYSPLIT.php) was used to investigate the possible aerosol sources and transport pathways. A total of 856 air mass back- trajectories (corresponding to the available AERONET data) for 72 hours from June to December 2011 at this site were computed and clustered. The near surface (1000 m) air mass was derived from the northwest (44\%, including Tajikistan, Uzbekistan and Turkmenistan), the west (36\%, including Afghanistan and the Iran Plateau), and from the southwest (20\%, including north Pakistan) (Fig. 8a). The HYSPLIT result is similar to the source tracing by dust geochemical composition at this site (Wu et al., 2009).

As shown above, there are several extremely high AOD events in August and October (Fig. 3). We clustered the frequency of the 72 hours backward trajectory for a typical event on August 25, 2011 (Fig. 8b). It can be seen that for high AOD days most air masses come from the west and northwest driven by the Westerlies. Additionally, we searched the natural hazard records from the NASA MODIS Terra satellite images (http://ladsweb.nascom.nasa.gov/browse_images/) to check whether there were dust events that could cause the extremely high AOD values during the observation. We found that there was a dust storm event on August 25, 2011 over northern Afghanistan and southern Tajikistan, which corresponded to the high AOD (0.33) on August 26, indicating that the dust plume can be lifted up to the mid-upper troposphere and transported eastward to Muztagh Ata. The high AOD values of August 24 and October 14 were possibly caused by dust storm events on August 23 and October 12 and 13 over the west Taklimakan, respectively. The satellite images of the related dust events are available in the Online Supplementary Materials.
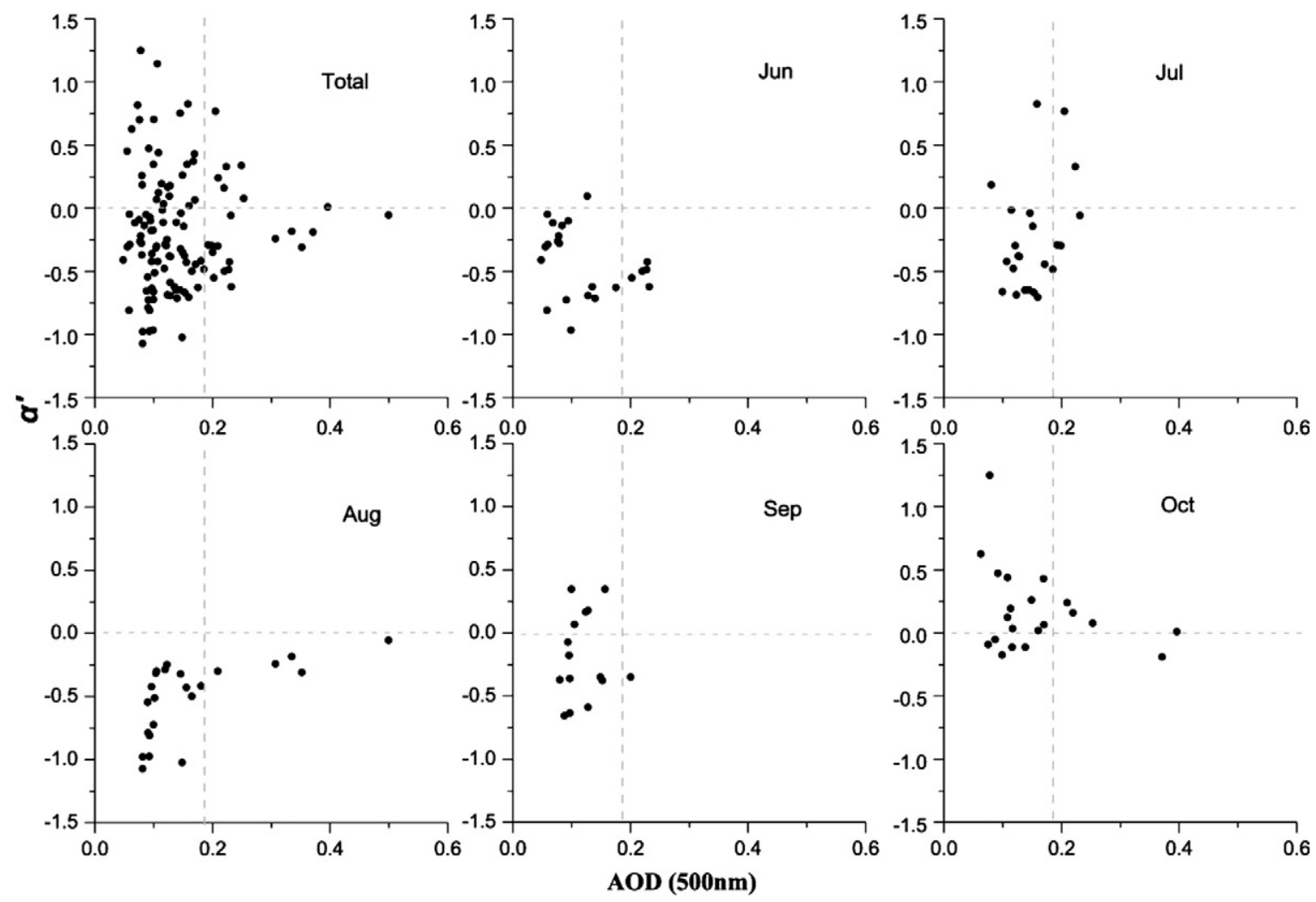

Fig. 7. Scatter plots of AOD (500 nm) and $\alpha^{\prime}$ from June to October in 2011 over Muztagh Ata. 


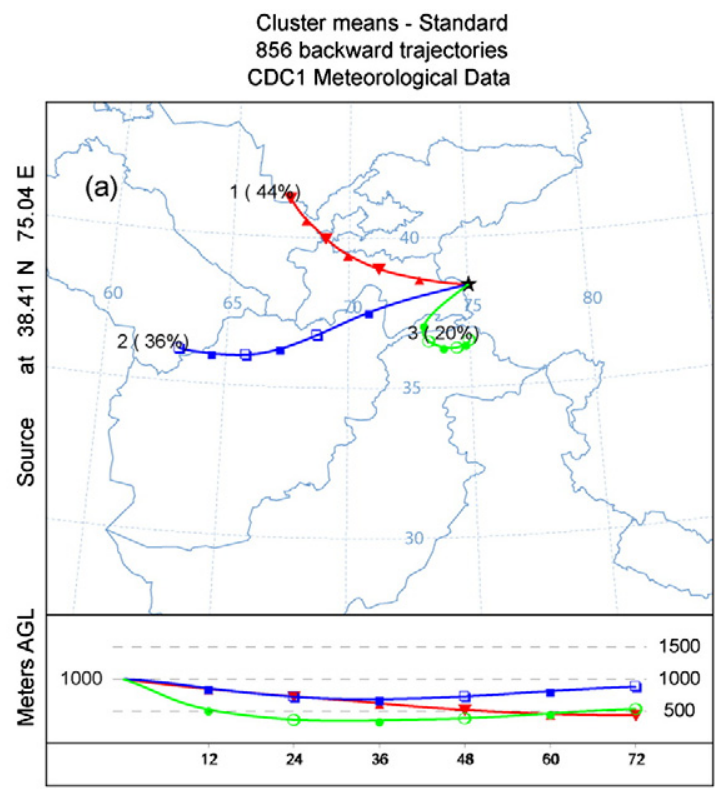

Trajectory Frequency

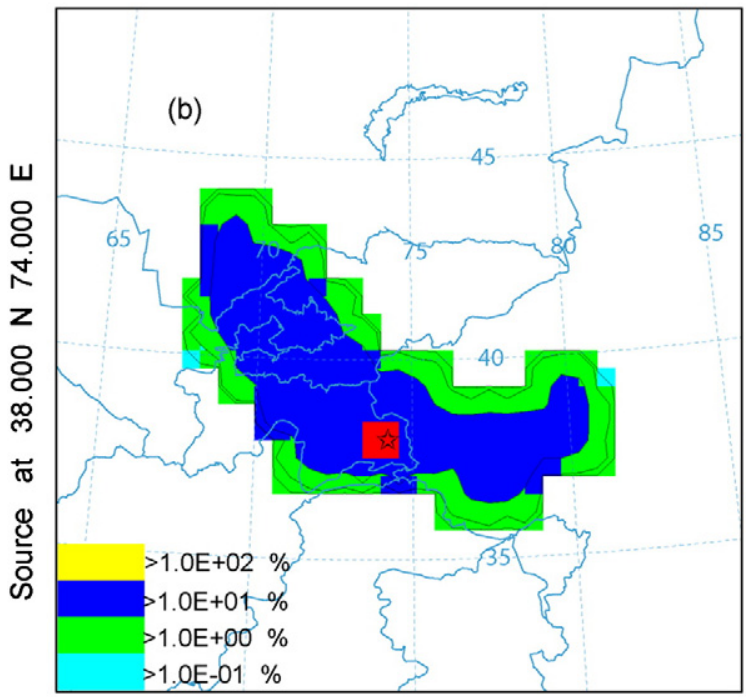

METEOROLOGICAL DATA

Fig. 8. The cluster plot of backward trajectories for the period for June to December 2011(a) and the frequency plot of three day backward trajectories on August 25, 2011 (b) at Muztagh Ata.

\section{Conclusion}

Aerosol optical properties over Mt. Muztagh Ata, Eastern Pamirs for the period June to December 2011 were analyzed using AERONET data, including AOD, $\alpha$, and volume size distribution. The averages of all daily AOD and $\alpha$ are $0.14 \pm$ 0.07 and $0.70 \pm 0.27$, respectively. The maximum monthly mean of AOD is $0.16 \pm 0.11$ in August, while the minimum monthly mean of AOD is $0.08 \pm 0.02$ in November. The high AOD is associated with the low $\alpha$, suggesting that coarse particles were related with high dust load. These results indicate that Muztagh Ata has a very clean atmospheric environment and that coarse particles dominate in this region.

The aerosol volume size distribution showed bimodal lognormal characteristics at Muztagh Ata, with a coarse mode radius of $3 \mu \mathrm{m}$ and a fine mode radius of $0.2 \mu \mathrm{m}$. Moreover, coarse particles are the dominant component of aerosol volume both in summer and autumn. There are differences in the coarse mode contribution to total aerosol volume in summer and autumn, while there are no significant differences in the fine mode.

The AOD value derived from MODIS satellite data was greater than that of AERONET AOD, with a difference of 0.1-0.4 on the daily timescale. However, the MODIS AOD has a similar trend to the AERONET. Therefore, ground-based observations can validate and calibrate the satellite data in order to improve the satellite retrieval products.

\section{Acknowledgments}

We are grateful to AERONET and MODIS team members for providing the observation data, Dr. S.F. Abdullaev (PhysicalTechnical Institute, Academy of Sciences of the Republic of Tajikistan) for sharing the AERONET data at Dushanbe site, the members of Muztagh Ata Station (ITP CAS) for helping the field work and Ms. Caroline Brimblecombe for improving the text. We also thank the editor and two anonymous referees for their helpful comments. This work is supported by NSFC (Grant No. 41190083, 41271074) and CAS Strategic Priority Research Program B (Grant No. XDB03030101).

\section{Appendix A. Supplementary data}

Supplementary data to this article can be found online at http://dx.doi.org/10.1016/j.atmosres.2014.10.013.

\section{References}

Alam, K., Trautmann, T., Blaschke, T., 2011. Aerosol optical properties and radiative forcing over mega-city Karachi. Atmos. Res. 101, 773-782.

Alam, K., Trautmann, T., Blaschke, T., Majid, H., 2012. Aerosol optical and radiative properties during summer and winter seasons over Lahore and Karachi. Atmos. Environ. 50, 234-245.

Alam, K., Trautmann, T., Blaschke, T., Subhan, F., 2014. Changes in aerosol optical properties due to dust storms in the Middle East and Southwest Asia. Remote Sens. Environ. 143, 216-227.

Cao, J.. Xu, B.Q, He, J.Q, Liu, X.Q. Han, Y.M., Wang, G.H., Zhu, C.S., 2009. Concentrations, seasonal variations, and transport of carbonaceous aerosols at a remote Mountainous region in western China. Atmos. Environ. 43, 4444-4452.

Che, H.Z., Wang, Y.Q., Sun, J.Y., Zhang, X.C., Zhang, X.Y., Guo, J.P., 2013. Variation of aerosol optical properties over the Taklimakan Desert in China. Aerosol Air Qual. Res. 13, 777-785.

Chu, D.A., Kaufman, Y.J., Ichoku, C., Remer, L.A., Tanré, D., Holben, B.N., 2002. Validation of MODIS aerosol optical depth retrieval over land. Geophys. Res. Lett. 29 (12). http://dx.doi.org/10.1029/2001GL013205.

Cong, Z.Y., Kang, S.C., Liu, X.D., Wang, G.F., 2007. Elemental composition of aerosol in the Nam Co region, Tibetan Plateau, during summer monsoon season. Atmos. Environ. 41, 1180-1187.

Cong, Z.Y., Kang, S.C., Smirnov, A., Holben, B., 2009. Aerosol optical properties at Nam Co, a remote site in central Tibetan Plateau. Atmos. Res. 92, 42-48.

Dubovik, O., Smirnov, A., Holben, B.N., King, M.D., Kaufman, Y.J., Eck, T.F., Slutsker, I., 2000. Accuracy assessments of aerosol optical properties retrieved from Aerosol Robotic Network (AERONET) Sun and sky radiance measurements. J. Geophys. Res. 105, 9791-9806.

Dubovik, O., Holben, B., Eck, T.F., Smirnov, A., Kaufman, Y.J., King, M.D., Tanré, D., Slutsker, I., 2002. Variability of absorption and optical properties of key aerosol types observed in worldwide locations. J. Atmos. Sci. 59, 590-608. 
Eck, T.F., Holben, B.N., Reid, J.S., Dubovik, O., Smirnov, A., O'Neill, N.T., Slutsker, I, Kinne, S., 1999. Wavelength dependence of the optical depth of biomass burning, urban, and desert dust aerosols. J. Geophys. Res. 104, 31333-31349.

Grosso, N., Paronis, D., 2012. Comparison of contrast reduction based MODIS AOT estimates with AERONET measurements. Atmos. Res. 116, 33-45.

Holben, B.N., Eck, T.F., Slutsker, I., Tanré, D., Buis, J.P., Setzer, A., Vermote, E. Reagan, J.A., Kaufman, Y.J., Nakajima, T., Lavenu, F., Jankowiak, I., Smirnov, A., 1998. AERONET - a federated instrument network and data archive for aerosol characterization. Remote Sens. Environ. 66, 1-16.

Kaufman, Y.J., 1993. Aerosol optical thickness and atmospheric path radiance. J. Geophys. Res. Atmos. 98, 2677-2692.

Kaufman, Y.J., Setzer, A., Ward, D., Tanré, D., Holben, B.N., Menzel, P., Pereira, M.C. Rasmussen, R., 1992. Biomass Burning Airborne and Spaceborne Experiment in the Amazonas (BASE-A). J. Geophys. Res. Atmos. 97, 14581-14599.

Middleton, N.J., 1986. A geography of dust storms in South-West Asia. Int. J. Climatol. 6 (2), 183-196.

Ningombam, S.S., Bagare, S.P., Sinha, N., Singh, R.B., Srivastava, A.K., Larson, E., Kanawade, V.P., 2014. Characterization of aerosol optical properties over the high-altitude station Hanle, in the trans-Himalayan region. Atmos. Res. $138,308-323$.

Ramanathan, V., Crutzen, P.J., Kiehl, J.T., Rosenfeld, D., 2001. Aerosols, climate, and the hydrological cycle. Science 294, 2119-2124.

Remer, L.A., Kaufman, Y.J., Tanré, D., Mattoo, S., Chu, D.A., Martins, J.V., Li, R.R. Ichoku, C., Levy, R.C., Kleidman, R.G., Eck, T.F., Vermote, E., Holben, B.N., 2005. The MODIS aerosol algorithm, products, and validation. J. Atmos. Sci. 62, 947-973.

Semenov, V.K., Smirnov, A., Aref'ev, V.N., Sinyakov, V.P., Sorokina, L.I., Ignatova, N.I., 2005. Aerosol optical depth over the mountainous region in central Asia (Issyk-Kul Lake, Kyrgyzstan). Geophys. Res. Lett. 32, L05807. http://dx. doi.org/10.1029/2004GL021746.
Smirnov, A., Holben, B.N., Eck, T.F., Dubovik, O., Slutsker, I., 2000. Cloudscreening and quality control algorithms for the AERONET database. Remote Sens. Environ. 73, 337-349.

Tanré, D., Kaufman, Y.J., Holben, B.N., Chatenet, B., Karineli, A., Lavenu, F., Blarel, L., Dubovik, O., Remer, L., 2001. Climatology of dust aerosol size distribution and optical properties derived from remotely sensed data in the solar spectrum. J. Geophys. Res. 106, 205-218.

Wake, C.P., Dibb, J.E., Mayewski, P.A., Zhongqin, L., Zichu, X., 1994. The chemical composition of aerosols over the eastern Himalayas and Tibetan Plateau during low dust periods. Atmos. Environ. 28, 695-704.

Wen, Y.P., Xu, X.B., Tang, J., Zhang, X.C., Zhang, Y.C., 2001. Enrichment characteristics and origin of atmospheric aerosol elements at Mt. Waliguan. Q. J. Appl. Meteorol. 12 (4), 400-408 (in Chinese).

Wu, G.J., Yao, T.D., Xu, B.Q., Tian, L.D., Li, Z., Duan, K.Q., 2008. Seasonal variations of dust record in the Muztagata ice cores. Chin. Sci. Bull. 53, 2506-2512.

Wu, G.J., Xu, B.Q., Zhang, C.L., Gao, S.P., Yao, T.D., 2009. Geochemistry of dust aerosol over the Eastern Pamirs. Geochim. Cosmochim. Acta 73, 977-989.

Xia, X.A., 2006. Significant overestimation of global aerosol optical thickness by MODIS over land. Chin. Sci. Bull. 51, 2905-2912.

Xia, X.A., Zong, X., Cong, Z.Y., Chen, H.B., Kang, S.C., Wang, P.C., 2011. Baseline continental aerosol over the central Tibetan plateau and a case study of aerosol transport from South Asia. Atmos. Environ. 45, 7370-7378.

Xin, J.Y., Wang, Y.S., Li, Z.Q., Wang, P.C., Hao, W.M., Nordgren, B.L., Wang, S.G., Liu, G.R., Wang, L.L., Wen, T.X., Sun, Y., Hu, B., 2007. Aerosol optical depth (AOD) and Ångström exponent of aerosols observed by the Chinese Sun Hazemeter Network from August 2004 to September 2005. J. Geophys. Res. 112, D05203. http://dx.doi.org/10.1029/2006JD007075.

Zhang, N.N., Cao, J.N., Ho, K.F., He, Y.Q., 2012. Chemical characterization of aerosol collected at Mt. Yulong in wintertime on the southeastern Tibetan Plateau. Atmos. Res. 107, 76-85. 